\title{
Composition of human adipose tissue from deep and subcutaneous sites
}

\author{
By C. G. D. BROOK \\ Department of Child Health, Institute of Child Health, \\ University of London, 30 Guilford Street, London, WCI
}

(Received 25 Fune 1970-Accepted 21 October 1970)

\begin{abstract}
1. Adipose tissue was obtained simultaneously from subcutaneous and deep sites in children undergoing elective surgery, and from different subcutaneous sites in adults. The lipid content and fatty acid composition were measured using gas-liquid chromatography and the number of cells counted after fixation in osmium tetroxide. The mean amount of lipid per cell was used as a measure of the size of the cells.

2. Cells from deep sites in children were significantly smaller $(P<0.001)$ than those from subcutaneous sites in the same individual. Cells from different subcutaneous sites were of similar size.

3. The fatty acid composition of the lipids was similar in tissue taken from the abdominal wall and from deep sites.

4. The fatty acid composition of adipose tissue from the lower leg showed an increase in the monounsaturated fatty acids and a decrease in the saturated fatty acids compared with the fatty acid composition of tissue from other subcutaneous sites.
\end{abstract}

The greater part of human adipose tissue is subcutaneous and most studies have been based on material obtained from this site. Few actual studies of a comparison between subcutaneous and deep sites have been reported. Baker (1969) estimated DNA in perirenal and subcutaneous fat, and found consistently more DNA in the perirenal tissue, although the difference only reached statistical significance in his youngest patients. Because stromal cells make a substantial contribution to the DNA content (Rodbell, I964), this observation does not necessarily mean that there are more adipose cells in deep sites: The present paper reports studies of the adipose cells from deep and subcutaneous sites in the same individual.

\section{EXPERIMENTAL}

Adipose tissue was obtained from children and adults of normal weight undergoing elective surgery for various conditions. Tissue was obtained from both subcutaneous and deep sites in twelve children (see Table $\mathrm{I}$ ); in two children and three adults, tissue was obtained simultaneously from two subcutaneous sites (see Table 3). The fatty acid composition of tissue obtained from the lower leg of nineteen subjects (adults and children) was compared with that obtained from other subcutaneous sites in sixty subjects (adults and children).

A portion of tissue (about ro-20 $\mathrm{mg}$ ) was weighed, homogenized in chloroformmethanol $(2: \mathrm{I}, \mathrm{v} / \mathrm{v})$ and the lipids were extracted overnight at room temperature. Total lipid (triglyceride) and fatty acid composition were estimated using quantitative gas-liquid chromatography by the method of Fosbrooke \& Tamir (I968). Initial 
experiments showed that the results obtained by estimating triglyceride from the total fatty acid content and triglyceride separated by thin-layer chromatography did not differ.

A second portion of tissue (about ro-20 $\mathrm{mg}$ ) was weighed and the number of cells was counted by the following modification of method 3 of Hirsch \& Gallian (1968). The sample, on a piece of nylon screen (pore size $253 \mu \mathrm{m}$, obtainable from Henry Simon Ltd, Stockport), was placed in a $5 \mathrm{ml}$ bottle containing about $3 \mathrm{ml}$ of the $2 \%$ osmium tetroxide in $0.05 \mathrm{M}$-collidine- $\mathrm{HCl}$ buffer, and fixed at room temperature for a minimum of $3 \mathrm{~d}$. After fixation, the tissue was easily disrupted by gentle pressure and the fixed cells were washed off the nylon screen with isotonic saline at $\mathrm{pH} 7 \cdot 4$. The screen was supported in a slit-sieve Buchner filter-funnel to which gentle suction was applied. The free cells were trapped on a $20 \mu \mathrm{m}$ screen attached to the stem of the funnel by a hose-clip, and were subsequently washed off with a measured amount of isotonic saline $\left(\mathrm{pH}_{7 \cdot 4}\right)$. For counting in the electronic cell counter the cells were suspended evenly by adding an appropriate volume of $50 \%(\mathrm{v} / \mathrm{v})$ glycerol-saline. Machine counts were checked by visual counting and found to agree. The coefficient of variation of the method on duplicate analyses was $7.5 \%$.

The mean lipid content of the cell was calculated from the total lipid content and the cell number.

\section{RESULTS}

Table I shows the total lipid content and the cell size of adipose tissue taken from both subcutaneous and deep sites in the same child. The mean lipid content of the adipose tissue from the deep sites was less $(0.02<P<0.05)$ than that from the subcutaneous sites; the size of the adipose cells from the deep sites was markedly

Table I. Total lipid content and cell size of adipose tissue from subcutaneous and deep sites in children

\begin{tabular}{|c|c|c|c|c|c|c|}
\hline \multirow[b]{2}{*}{$\begin{array}{c}\text { Age } \\
\text { (years) }\end{array}$} & \multicolumn{3}{|c|}{ Subcutaneous } & \multicolumn{3}{|c|}{ Deep } \\
\hline & Site & $\begin{array}{l}\text { Lipid } \\
\text { content } \\
\text { (\%wet } \\
\text { weight) }\end{array}$ & $\begin{array}{l}\text { Cell size } \\
\text { ( } \mu \text { g lipid } / \\
\text { cell })\end{array}$ & Site & $\begin{array}{l}\text { Lipid } \\
\text { content } \\
\text { (\% wet } \\
\text { weight) }\end{array}$ & $\begin{array}{l}\text { Cell size } \\
\text { ( } \mu \text { g lipid } / \\
\text { cell })\end{array}$ \\
\hline 0.8 & & $(80 \cdot 2$ & 0.35 & Perinephric & $73 \cdot 7$ & 0.06 \\
\hline$I \cdot 5$ & & $73 \cdot 9$ & 0.25 & Perinephric & $70 \cdot 4$ & 0.15 \\
\hline$I \cdot 7$ & & $71 \cdot 9$ & 0.07 & Pelvic & $70 \cdot 2$ & 0.06 \\
\hline $2 \cdot 6$ & & $78 \cdot 0$ & 0.45 & Perinephric & $68 \cdot 0$ & 0.17 \\
\hline $3 \cdot 2$ & & $66 \cdot 2$ & 0.24 & Perinephric & $66 \cdot 8$ & 0.09 \\
\hline $3 \cdot 4$ & & $8 I \cdot 3$ & 0.22 & Pelvic & 73.4 & 0.18 \\
\hline $3 \cdot 5$ & Abdominal & 70.7 & 0.36 & Omental & $6 x \cdot 2$ & $0 \cdot I I$ \\
\hline $4^{2} 2$ & wall & $70 \cdot 9$ & 0.53 & Retroperitoneal & $71 \cdot 5$ & O.I7 \\
\hline $4 \cdot 9$ & & $7 I^{\cdot} 7$ & 0.30 & Pelvic & $59^{\circ} 0$ & 0.22 \\
\hline $5 \cdot 2$ & & $63 \cdot 2$ & $0 \cdot 16$ & Pelvic & $69 \cdot 3$ & 0.10 \\
\hline $7 \cdot 2$ & & $79^{\circ} 5$ & 0.22 & Pelvic & $60 \cdot 7$ & 0.09 \\
\hline$I x-4)$ & & $166 \cdot 3$ & 0.23 & Mesenteric & $66 \cdot 5$ & 0.14 \\
\hline Mean & & $72 \cdot 8 *$ & $0 \cdot 28 * *$ & & $67 \cdot 6 *$ & $0.13^{* *}$ \\
\hline SD & & $5 \cdot 9$ & 0.13 & & $4 \cdot 9$ & 0.05 \\
\hline
\end{tabular}


reduced $(P<0.001)$. In the children the fatty acid composition of the lipid did not differ between abdominal wall and deep sites (Table 2). Histological examination (Dr David Hull) showed both samples to be white adipose tissue.

Table 2. Fatty acid composition (major components, weight percentages of the total) of adipose tissue from subcutaneous and deep sites in children

(Means and standard deviations)

\begin{tabular}{|c|c|c|c|c|c|c|}
\hline & $\mathrm{C}_{14: 0}$ & Cr6:0 & Ci6:I & Ci 8:0 & Cr8:I & $\mathrm{Cr}_{1} 8: 2$ \\
\hline Subcutaneous sites & $\begin{array}{r}5.8 \\
+\mathrm{I} \cdot 0\end{array}$ & $\begin{array}{r}25 \cdot 0 \\
\pm r \cdot 3\end{array}$ & $\begin{array}{r}6.1 \\
\pm I .4\end{array}$ & $\begin{array}{r}8.5 \\
\pm 2.2\end{array}$ & $\begin{array}{r}47 \cdot 3 \\
\pm 1 \cdot 7\end{array}$ & $\begin{array}{r}6.8 \\
+3.4\end{array}$ \\
\hline Deep sites & $\begin{array}{r}5.8 \\
\pm 10\end{array}$ & $\begin{array}{r}26 \cdot 4 \\
\pm 1 \cdot 3\end{array}$ & $\begin{array}{r}5.0 \\
\pm 14\end{array}$ & $\begin{array}{r}9 \cdot 2 \\
\pm 2 \cdot 2\end{array}$ & $\begin{array}{r}45.9 \\
\pm 1.7\end{array}$ & $\begin{array}{r}7.0 \\
+3.4\end{array}$ \\
\hline
\end{tabular}

Table 3. Cell size and lipid content of adipose tissue from different subcutaneous sites in children and adults

\begin{tabular}{|c|c|c|c|c|c|c|}
\hline $\begin{array}{c}\text { Age } \\
\text { (years) }\end{array}$ & Site & $\begin{array}{c}\text { Lipid } \\
\text { content }(\%)\end{array}$ & $\begin{array}{c}\text { Cell size } \\
(\mu \mathrm{g} \text { lipid/cell) }\end{array}$ & Site & $\begin{array}{c}\text { Lipid } \\
\text { content }(\%)\end{array}$ & $\begin{array}{c}\text { Cell size } \\
(\mu \mathrm{g} \text { lipid/cell) }\end{array}$ \\
\hline $6 \cdot 5$ & $\begin{array}{c}\text { Anterior } \\
\text { abdominal wall }\end{array}$ & $67 \cdot 5$ & 0.14 & Perineal & $64 \cdot I$ & 0.15 \\
\hline $12 \cdot 5$ & Buttock & 87.4 & 0.76 & Arr & $82 \cdot I$ & 0.79 \\
\hline $34 \cdot 0$ & Groin & $67 \cdot 5$ & 0.59 & An] & 64.2 & 0.69 \\
\hline $57^{\circ} 0$ & Groin & $73 \cdot 5$ & $0.8 \mathrm{r}$ & Ankle & 75.7 & 0.76 \\
\hline $59^{\circ} 0$ & Groin & $63 \cdot 6$ & 0.70 & Ankle & $5^{6 \cdot 7}$ & 0.69 \\
\hline
\end{tabular}

Table 4. Fatty acid composition (major components, weight percentages of the total) of adipose tissue from subcutaneous sites in children and adults

(Means and standard deviations)

\begin{tabular}{|c|c|c|c|c|c|c|}
\hline Site & $\mathrm{CI}_{\mathrm{I}}: 40$ & $\mathrm{C}_{\mathrm{I}}: 60$ & $C_{I}: 6 \mathrm{I}$ & $\mathrm{Cr}_{\mathrm{I}}: 80$ & $\mathrm{Cr}_{\mathrm{r}}: 8 \mathrm{I}$ & $C_{1}: 82$ \\
\hline $\begin{array}{l}\text { Subcutaneous } \\
\text { (other than lower } \\
\text { leg) }(n=60)\end{array}$ & $\begin{array}{r}5 \cdot I \\
\pm \mathrm{I} \cdot \mathrm{I}\end{array}$ & $\begin{array}{r}24.7 \\
+3.9\end{array}$ & $\begin{array}{r}5.8 \\
\pm 1.5\end{array}$ & $\begin{array}{r}7 \cdot 9 \\
\pm 1.7\end{array}$ & $\begin{array}{r}46 \cdot 6 \\
\pm 2 \cdot 7\end{array}$ & $\begin{array}{r}7 \cdot 7 \\
+2.5\end{array}$ \\
\hline Lower leg $(n=\mathrm{Ig})$ & $\begin{array}{r}3.7 \\
\pm 10\end{array}$ & $\begin{array}{r}19.6 \\
\pm 3.2\end{array}$ & $\begin{array}{r}\text { I2.1 } \\
\pm 3.7\end{array}$ & $\begin{array}{r}2.8 \\
\pm \mathrm{r} \cdot 4\end{array}$ & $\begin{array}{r}51.5 \\
\pm 3.5\end{array}$ & $\begin{array}{r}7.5 \\
+2.2\end{array}$ \\
\hline $\begin{array}{l}\text { Significance of } \\
\text { difference, } P\end{array}$ & $<0.001$ & $<0.001$ & $<0.001$ & $<0.001$ & $<0.001$ & NS \\
\hline
\end{tabular}

The total lipid content and cell size of adipose tissue taken simultaneously from different subcutaneous sites in children and adults did not differ (Table 3). However, the fatty acid composition of adipose tissue from the lower leg differed from that at other subcutaneous sites (Table 4 ). In the lower leg the monounsaturated fatty acids (palmitoleic and oleic) were increased and the saturated fatty acids (myristic, palmitic and stearic) were decreased. The percentage of linoleic acid did not differ. 


\section{DISCUSSION}

Increasing interest is being focused on the size and number of adipose cells, particularly in obesity. Because presently available methods make the assumption that all adipose cells have the same mean size (Hirsch, Knittle \& Salans, I966), the finding in the present study that adipose cells from deep sites are smaller than those from superficial sites invalidates the calculation of total cell number based on a subcutaneous sample. However, because the majority of adipose tissue is subcutaneous and the mean cell size from different subcutaneous sites is the same, it is probably still justifiable for practical purposes to base an estimate of total cell number on values derived from this site.

Differences in metabolic activity between subcutaneous and deep adipose tissue have been demonstrated both in experimental animals (Jelinková-Tenorova 8 Hruza, I963) and in man (Carlson \& Hallberg, I968). These studies have shown that the response to noradrenalin was greater in deep adipose tissue than in subcutaneous adipose tissue. The difference in cell size may reflect these differences in metabolic activity. Baker (1969) suggested that the difference in DNA content between subcutaneous and perirenal adipose tissue might be due to persistence of brown adipose tissue in deep sites. No evidence for this has been found in the present study.

The similarity between the fatty acid composition of the lipids in tissue from the abdominal wall and from deep sites confirms the observations of Kingsbury, Paul, Crossley \& Morgan (I96I).

The difference in fatty acid composition of adipose tissue from the lower leg compared with that from other sites confirms the findings of McLaren, Read \& Chimbe ( 1962 ), who suggested that the increase in monounsaturated fatty acids at the expense of saturated fatty acids may be related to differences in ambient temperature. Henriques \& Hansen (I9OI) showed that, in the hog, the superficial layers of fat contained more unsaturated fatty acids than the deeper layers and that this difference could be reduced by measures designed to raise the temperature of the superficial layers.

I would like to thank Dr June Lloyd for her help and the Wellcome Trust for financial support.

\section{REFERENCES}

Baker, G. L. (1969). Am. F. clin. Nutr. 22, 829.

Carlson, L. A. \& Hallberg, D. (I968). F. Lab. clin. Med. 71, 368.

Fosbrooke, A. S. \& Tamir, I. (I968). Clin. chim. Acta 20, 517.

Henriques, V. \& Hansen, C. (I90I). Scand. Arch. Physiol. Ir, I5I.

Hirsch, J. \& Gallian, E. (1968). F. Lipid Res. 9, I 10.

Hirsch, J., Knittle, J. L. \& Salans, L. B. (1966). F. clin. Invest. $45,1023$.

Jelinková-Tenorova, M. \& Hruza Z. (1963). Gerontologia 7, 168.

Kingsbury, K. J., Paul, S., Crossley, A. \& Morgan, D. M. (196r). Biochem. F. 78, 54r.

McLaren, D. S., Read, W. W. C. \& Chimbe, A. (1962). Clin. Sci. 23, 247.

Rodbell, M. (1964). F. biol. Chem. 239, 753 . 